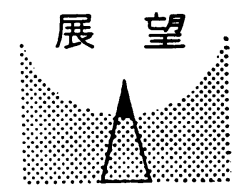

\title{
舶用機関の二，三の部材に関する 最近の寿命評価*
}

\author{
中村 宏 ${ }^{* *}$. 中野英明 ${ }^{* * *}$ \\ 恒成利 康 ${ }^{* * * *}$ 堀川武 ${ }^{* * * *}$
}

\section{1.はしがき}

舶用機関としては古くから蒸気タービン，ディーゼル 機関が用いられてきている1．また艦艇用にはガスター ビンなどあ装備されるようになってきた ${ }^{2,3)}$ ：てれらの 製品は長年の経験により着実に改良が加えられ，現在に 至っている，一方，てれら製品の高性能化，高い信頼性 と安全性，低コスト，軽量化などに対する要求がますま す高くなっているとともに，ディーゼル機関などにおい ては開発期間の短縮か強く求められている. したがって, 従来のような試行錯誤的な改良により製品を成熟させる ような手法は使えず，解析的手法を主体として，乙れま での経験をその中に生かすような方法により製品の開発 や改良を行ってゆかねばならない。

さて，機関が，その必要之される寿命の間において， 十分に安全，かつ高い信頼性を維持するためには，それ を構成する部分が必要な性能を十分に発揮するととあに 各々の部材の強度が十分でなりればならない. 性能面の 評価は実験機関によって比較的短時間に評価できるが, 強度面，とくに疲労強度については長時間の使用の後に 問題点が顕在化することが多く，また加速試験では実際 と違った評価をしてしまうことがある゙ ため, 試験の方 法は非常に難かしい.

疲労強度評価に関して，以前に “疲労寿命推定”之題 して本学会誌に概略をとりまとめた ${ }^{5)}$ ：今回は二・三の 部材の疲労強度評価例について説明するとともに，今後 に残された問題点を明らかにする.

\section{2. 舶用ディーゼル機関の強度評価}

ディーゼル機関において強度評価がとくに重要な部材 は，i）燃焼室壁部材（ピストンクラウン，シリンダカバ 一, シリンダライナー), ii ) 連接棒, iii) クランク軸, 及 び架構などである.とれらの部材については有限要素法 を使った応力解析 ${ }^{6)}$, 振動解析などにより部材の応力を 求め, 疲労強度評価を行うとともに, 新型機関において は実験機関による性能面の検討之耐久試験が行われる。

\footnotetext{
* 原稿受付 昭和 58 年 6 月 6 日

** 正会員 川崎重工業(株)技術研究所(明石市川崎町 1-1)

*** 正会員 川崎重工業(株)(神戸市中央区東川崎町 3-1-1)

**** 川崎重工業(株)技術研究所(明石市川崎町 1-1)
}

しかし耐久試験には長い時間と多くの費用を必要とする ため，必ずし屯必要十分な試験ができるとはかぎらない. そのため主要部材については解析で得た応力值と材料の 疲労試験をむとにして疲労寿命の予測を行って安全性を 確認している ${ }^{6)}$. 以下にその二・三の例について説明す る.

2.1 ピストンクラウンの寿命評価 ピストンク ラウンに発生する応力は燃焼面と冷却面の温度差によっ て生じる熱応力之爆発によって生じるガス圧応力であり, 前者に後者の応力が重畳した重畳波形となり，乙れが機 関の発停にとあなって間欠的に繰返される.すなわち， ガス圧応力の繰返しばかりでなく，熱応力の繰返しによ ってあ疲労損傷が生じる ${ }^{7,8)}$ ため, 熱応力を一定の平均 応力とみなした従来の疲労強度評価法では実情に合った 評価はできない。このような波形下の疲労は間欠波形下 の疲労強度 ${ }^{9)}$ として実験研究が行われるようになり，そ の成果が燃焼室壁部材の寿命評価に活用されている ${ }^{8)}$.

間欠波形下では，熱応力振幅に比べて重畳するガス圧 応力の振幅が小さくても，熱応力が繰返されるために予 想外の大きな損傷がガス圧応力の繰返しによって生じる. この点を考えに入れた疲労寿命推定の手順の一例を図 1 に示す ${ }^{10)}$. 乙の図における各々の評価手順について簡単 に説明する.

i）実働波形のモデル化 ピストンクラウンに生じ る応力波形は負荷の変動によって幾らか変わるが，基本 的には起動一停止によって生じる熱応力にガス圧応力が 重畳した間欠波形によって代表させることができる.

ii）弾性応力の変換 鋳造欠陥や切欠き部分におい て生じる局部的な降伏，あるいは平滑部分であってあ繰 返し応力が高い部分では材料の降伏応力が低下するため 部分的に塑性変形が生じ, 弾性応力解析で求めた応力値 をそのまま用いて寿命推定することはできない，そのた め図示のように材料の動的応力ーひずみ関係と Neuber の式 ${ }^{11)}$ ，あるいは公江の式 ${ }^{12)}$ 用いて弾性応力から， 塑性変形が生じた後に作用していると思われる応力を推 定しなりればならない，ただし，応力解析において弾塑 性解析を行っているときはこの手順は必要でない。

iii）平均応力の評価 寿命推定に使う $S-N$ 線図は 両振り応力, あるいは完全片振り応力下で疲労試験した あのであるため, 任意の大きさの平均応力が疲労強度に 

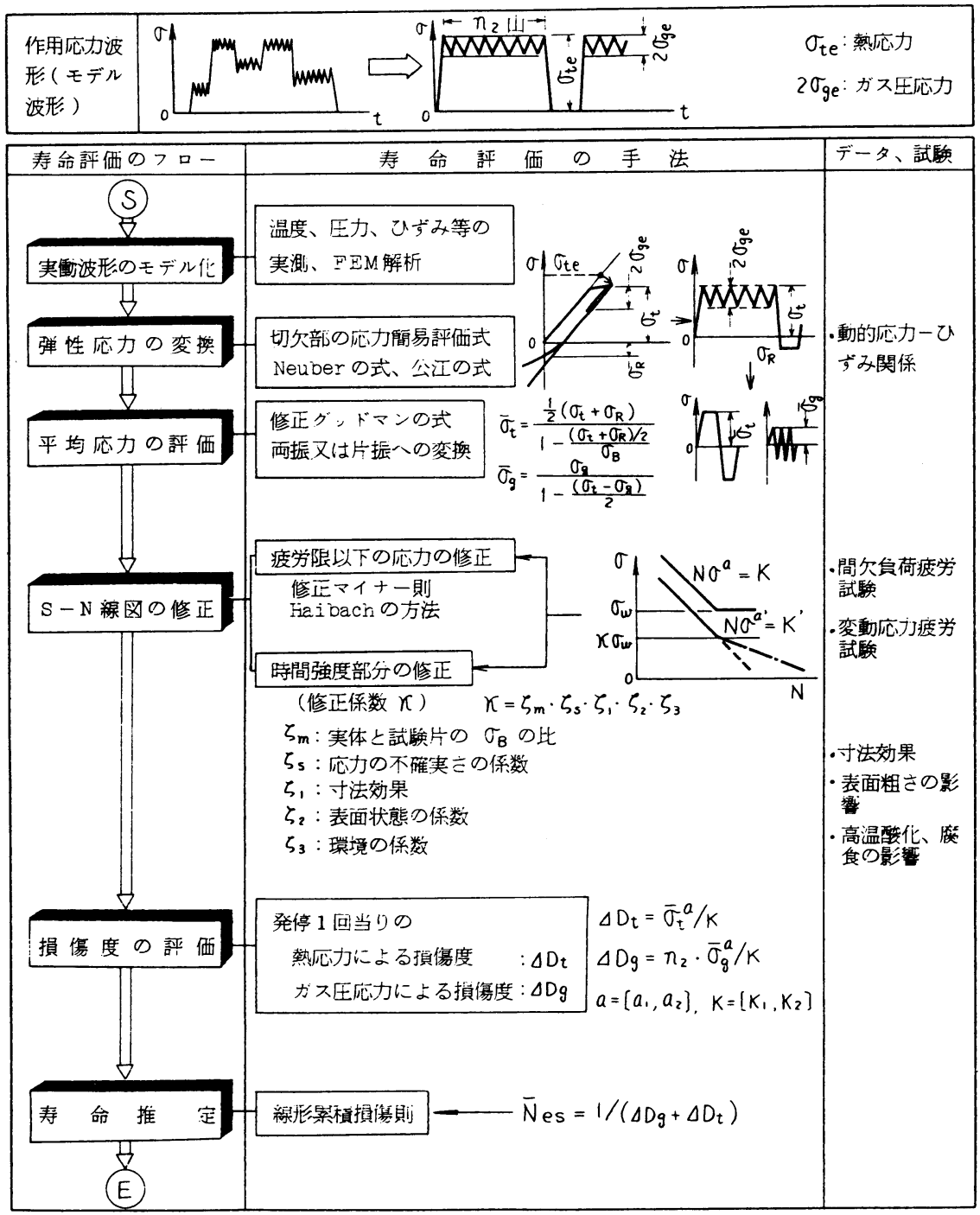

図 1 ピストンクラウンの疲労寿命推定の手順

及ぼす影響を修正グッドマンの式 ${ }^{13)}$ を用いて評価し，そ の換算応力振幅 $\sigma_{\mathrm{t}}$ を求める.

図 1 では両振り応力振幅へと換算する場合を示す.

iv ） $S-N$ 線四の修正 寿命推定に使う $S-N$ 線図 は試験片と実物との差を考慮して図示のような種々の影 響因子を考えて修正したものを用いる必要がある゙ ${ }^{6)}$ と くに疲労限以下の応力が疲労寿命に大きく効くため, 修 正マイナー則(図中の破線)やHaibachの方法(図中の一 点鎖線)を用いて寿命推定に使う $S-N$ 線図を作成しな ければならない14)。

V) 損傷評価之寿命推定 機関の発停 1 回当りの疲 労損傷は熱応力の繰返しによるものと, ガス压応力の繰 返しによるものとからなり，両者の和で疲労損傷度を表 わす.

vi）ピストンクラウンの寿命推定結果４サイクル
中高速ディーゼル機関のピストンクラウンについて寿命 評価した結果を図 2 亿示す．材料はFV $607 * 1$ であり， $S-N$ 線図の修正係数の值は図中に示した. とくにての 機関は応力の計算を行っているとと，試験片採取素材の 鍛造比が実機と同一であるとと,クラウンは機械仕上げ されていること，及び油冷却であるために腐食の影響を 考えなくてもよいてとから， $\boldsymbol{\zeta}_{\mathrm{s}}=\boldsymbol{\zeta}_{1}=\boldsymbol{\zeta}_{2}=\boldsymbol{\zeta}_{3}=1.0$ とし た。一方， $\zeta_{\mathrm{m}}$ を 0.8 にったのは試験片用に作った素材 では強度が実体よりも高く出る傾向にあるととを考えた ためである.

$S-N$ 線図の疲労限以下の部分の修正はHaibachの方 法を用いた. これは 2 サイクルディーゼル機関のピスト ンクラウンの例ではこの方法が実際寿命に比較的近い寿 命を与えるととが分っている ${ }^{8)}$ のでての方法を用いた. 


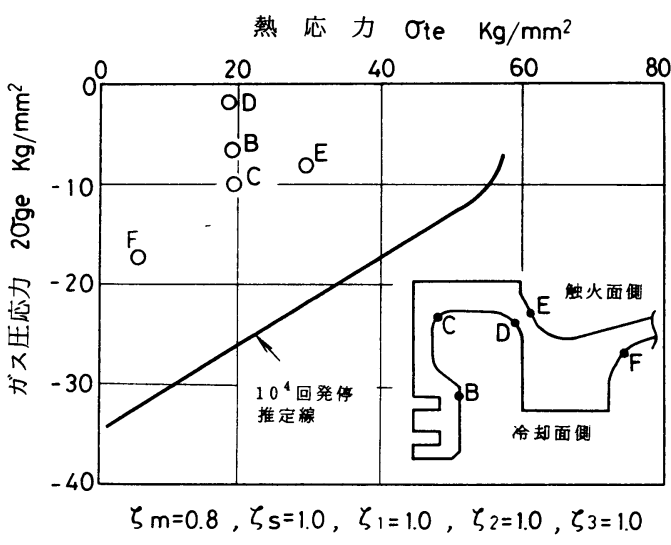

図 2 ピストンクラウンの寿命評価例

さらに重畳山数 $n_{2}$ は $3.6 \times 10^{4}$ とした*2.

本機関の必要発停回数として $10^{4}$ 回が目標值であるの で，それをパラメータにとったときの熱応力とガス压応 力の関係を求めたのが図中の実線である. 一方, ピスト ンクラウンの応力解析で応力值が比較的高かった位置を 図中に植点しているが, $10^{4}$ 回発停の推定線よりはるか に低い応力状態であり，ての機関のピストンクラウンは 十分に安全であると言える.

2.2 連接棒 中高速ディーゼル機関では連接棒の 破損は 2 次損傷を招くので，その設計には注意が必要で ある. 連接棒には爆発応力, 慣性力及び摇動運動にとも なう応力が作用する. 寸法的に制約のある空間で作動し ている部材であるため, 疲労損傷の発生位置は小端部や 大端部のつけ根部分, あるいはボルトに多かったが, 最 近では応力解析によって最適形状に近い形とすることが できるようになったとと，及び材料の選択範囲が広くな り，強度の高い材料が使われるようになったため従来の ような疲労損傷の問題はほとんどなくなった. それに代 って最近問題となっているのは大端部のフレッチング発 生, 及びフレッチング発生部の疲労強度低下の問題であ る. ての部分に対する評価法としては, 軸受のクラッシ ュ形メタルの面圧と相対すべり量を有限要素法 (FEM) を使った解析によって求め, 実機でのフレッチング発生 の実績からその限界を求め, 新しい大端部に対して対応 する方法をとっている. 図 3 はその一例であり*3, 限界 線の範囲内に入るように大端部形状, メタルのクラッシ 二量, ボルト締付け力などを決めている.

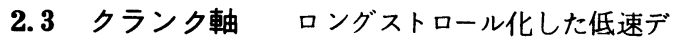
イーゼル機関のクランク軸で問題となるのはクランク腕 のつけ根部分においてクランクの縌振動によって発生す る曲げ応力である. 通常ての振動は設計段階で解析によ って知るととができ，共振しないようになっている，し

*2 発電用機関として 30 分に 1 回の発停を考えている.

*3 基準面圧とはメタルをクラッシュした時に生ずる面圧とし ている.

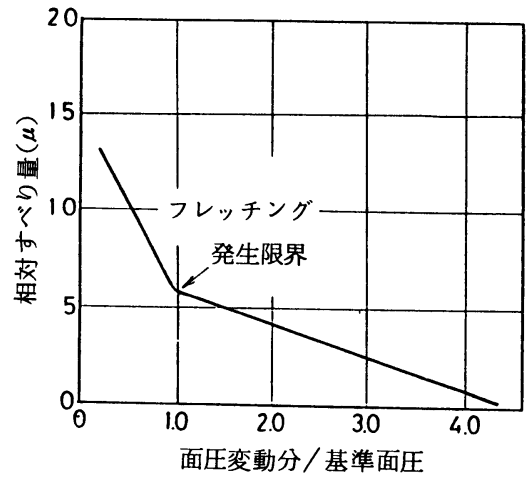

図 3 フレッチング発生限界

かし機関全体の軽量化のため架構が溶接構造などになる と, 架構とクランク軸の連成を考慮した振動解析を行っ

て, 発生応力を求め, 安全性を評価することが大切であ る.

2.4 架 跷 架構は構造が複雑であり, 荷重の着 力点が多く, 従来はその応力変形解析はほとんど不可能 であった. 光弾性応力解析などによって試行錯誤の繰返 しで設計が行われていた. しかし，最近の応力解析技術 はこのような複雑なものであ十分な精度で計算評価が可 能になった。

\section{3. ガスタービンの強度評価}

舶用に使われるガスタービンは航空機に用いられてい たあのが，主として艦艇用に転用されている．とのよう な転用型が使われるのは，その信頼性の高さによるもの と思われる. この場合に考えておく必要のあることは， 航空機と違って海上での稼動であるため塩分濃度の高い 環境中で使用されるため, コンプレッサ動翼の腐食疲労, 及びタービン動翼の高温腐食疲労強度の問題である ${ }^{3)}$.

さて，ガスタービンにおいて強度上最も重要な部材は 動翼及びディスクである．乙の部材は過去に蓄積された 多くの経験のあとに強度設計が行われてきている. しか るに新しく開発した材料の採用，エンジン開発期間の短 縮及び効率化，FEMを使った応力解析の発達により複 雑な形状や接触部分の応力を計算できるようになった 22 こと, 材料の高温強度評価技術の進歩などにより強度評 価に解析的手法がとり入れられるようになってきた.

とくに応力解析技術の進歩, 材料の高温強度試験法の 発達によもない，新しく開発した材料の評価を実機の稼 動状態を勘案したかなり高いレベルで行おうとする機運 が高まってきた.

図 4 はガスタービン動翼翼根部の寿命推定手順の一例 である ${ }^{15)}$. この場合は起動一停止にとあなって繰返され る遠心応力のうえに翼振動によもなう微小波が重盢する 応力波形となり，ピストンクラウンと同様に間欠波形で モデル化できる. また寿命評価のフローもピストンクラ ウンとほぼ同じであるが, クリープ損傷評価が加わる. 

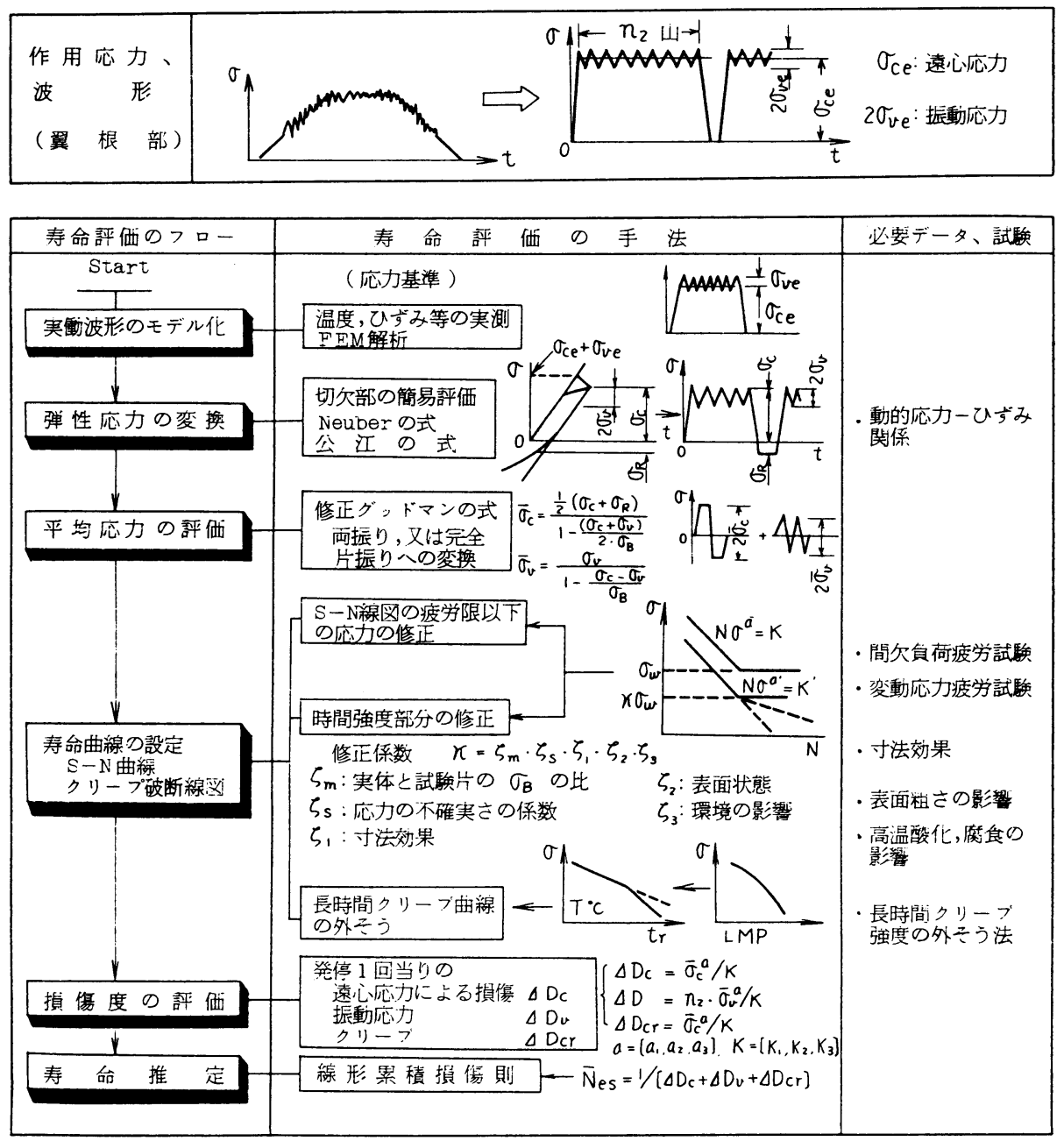

汹 4 ガスタービン動翼翼根部の寿命推定手順の例

各々の項目についての説明はピストンクラウンの場合と 重複するので省略するが, 翼根セレーション部分の応力 が弾塑性解析によって求められているようなときは弾性 応力の変換は必要でなくなる.

四 5 は起動一停止回数 $\bar{N}$ をパラメータにとった ときの遠心応力と振動応力の許容範囲を計算した 例である. $S-N$ 線凩の修证係数はすべて 1 とし ている. 疲労限以下の応力の評価としてHaibach の方法を用いた場合について $K_{\mathrm{t}}=1.0$ と 2.0 を比較 すると後者の場合が許容範四は非常に狭くなる. すなわち，鋳造欠宿などが存在すると安全性がか なり低くなることが分る.

Haibachの方法と修正マイナー則を比較すると 後者のほうが許容範囲が狭くなる.なお Inconel $713 \mathrm{LC}$ などの Ni 基鋳造合金ではHaibachの方法 よりも，もう少し $S-N$ 線図が長寿命側となるこ とが間欠波形下の実験により分っている ${ }^{15)}$ ので,
実際には図 5 の許容範囲は広くなる．とくに振動応力振 幅の小さい部分で範网が広くなる割合が大きい，一方， ここではクリープ損傷の評価を行っていないが，乙の材 料で $600^{\circ} \mathrm{C}$, 遠心応力 $40 \mathrm{~kg} / \mathrm{mm}^{2}$ 程度以下ではクリー

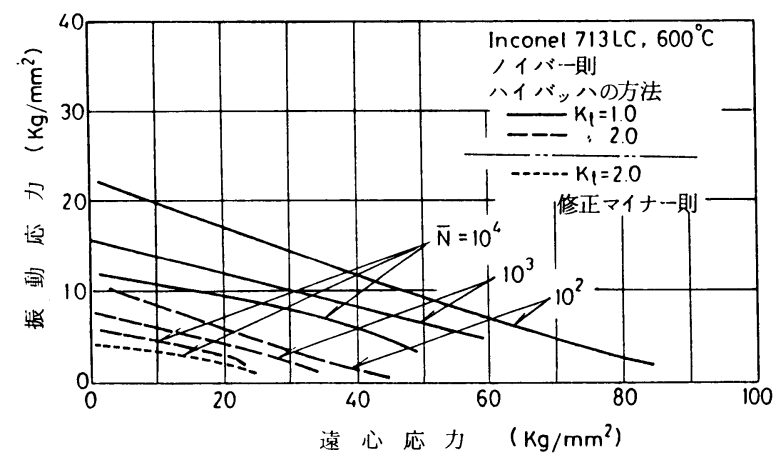

図 5 ガスタービン動翼翼根部の寿命推定例 
プ損傷が疲労損傷に比較して大きくないので考虑してい ない。しかし，それ以上の応力で非常に長時間になると 考虑する必要がでてくるが，実際にはそれ程大きな遠心 応力が生ずるような設計となっていないのが実情である。

\section{4. 寿命評価上の問題点}

寿命推定の手順について説明したが，ピストンクラウ ンの場合は推定寿命之実際の寿命を比較し，その問題点 についてある程度把握されているが，ガスタービン動翼 については今後に期待しなければならない。こてではピ ストンクラゥンでの経験にもとづいて寿命評価上の問題 点について説明する.

4.1 応力計算 部材に作用している応力は FEM を用いた応力解析によって求めるてとが普及しているが, ピストンクラウンの場合ガス圧応力は比較的精度よく求 まる. しかし熱応力については計算のために必要な温度 分布，熱伝達係数などのデータの精度が計算結果に大き く影響するが，ある程度の仮定はやむを得ないのが実情 である．一方，ガスタービン動翼の場合は遠心応力は比 較的精度よく求まるが，振動応力は正確につかむととは 難かしい、流体力, 翼根のセレーション部における減衰 係数が正しくつかめないため, 計算した応力の精度も十 分とは言えない．また翼の場合は共振の有無が寿命を大 きく左右する，通常の運転状態では共振しない上うに設 計されているが, 負荷の急激な変動, 起動一停止時の非 定常な状態など共振に対する要因が存在する以上，共振 した場合の検討は行っておく必要があろう。もし，共振 が皆無であれば遠心応力のみの繰返しとなり，低サイク ル疲労寿命だけを考えればよいので評価は簡単になる.

\section{2 弾性応力の変換 部材の応力が完全に弾性} 範囲内であれば問題はないが，熱応力，遠心応力は比較 的高く，また降伏点以下であってもその繰返しにともな って材料の降伏応力が低下し, 弾性範囲の応力と思って いたあのが，降伏応力を越えている結果となることがあ る.さらに鋳造欠陥が発生するような場合には，その部 分は局部的に高い応力となるため塑性変形が生じる. こ のような点を寿命評価に反映させる目的で弾性応力の変 換を行っている. ての変換に执いて使用する材料の応力 一ひずみ関係式として Incremental Step 試験やCompanion Specimen法によって得たものを用いているが' ここで得られた関係が寿命評価に使うために，その材料 の特性を十分に表わしたものとなっているか，否かが問 題である. てのような試験法で得られた応力ーひずみ関 係式は切欠き試験片の $S-N$ 線図を推定するのに使える ことは分っているが ${ }^{12)}$, 間欠波形やその他の実働波形に 使ったときにも，推定寿命と実際寿命は工学的に許容し うるばらつきの範囲に入るか否かの検討が必要である.

4.3 修正係数 $\kappa \quad S-N$ 線図の修正係数 $\kappa$ は図示 のようにそれぞれの因子についての係数の積で定義して いる ${ }^{17)}$ が，乙れは便宜的なものである.また，それぞれ
の因子の組合せたときの条件での実験研究もほとんどな く，実験を行うにあ時間がかかるため現時点ではとりあ えず図示の考え方を採用しておき，研究の進展につれて 改良してゆかざるを得ない.

疲労限以下の $S-N$ 線図の修正については間欠波形 ${ }^{9)}$ をはじめ重畳波形 ${ }^{18)}$ や変動応力振幅試験結果が必要であ $ろ^{19)}$

てのような実験を行うには，一定応力振幅の繰返しに よる $S-N$ 線図を求めるのに比べてはるかに多くの時間 を要するので必要なデータがなかなか蓄積されない. 図 6 は我が国にて行われたこの種実験データの概数を調査 した結果である. 間欠波形下のデータは他のあのに比へ てはるかに少ない. 間欠波形下の疲労では重冨二次波の 応力振幅が, 平均応力一定の疲労限以下の大きさであっ ても, 一次波 (平均応力) が変動するてとによって最大応 力（一次波十二次波の応力）によって疲労損傷が生じるた め，二次波によっても疲労損傷が生じる．乙れはあたか 屯変動応力振幅試験において疲労限以上の一次応力の次 に作用する疲労限以下の二次応力によっても疲労損傷が 生じるようになることと同じ現象であり, 現在のところ データの多い変動応力振幅試験結果の知見を参考にして 間欠波形を受ける部材の寿命推定を行っている. とくに 疲労限以下の $S-N$ 線図のとり方によって推定寿命は大 幅に変化するので必要な間欠波形下の実験データを早急 に蓄積することが大切である.

4.4 平均応力の評価 平均応力が疲労強度に及 ぼす影響を評価するため，上記の寿命推定手順では修正 グッドマンの式を用いているが, 平均応力 $\sigma_{\mathrm{m}}$ 之応力振 幅 $\sigma_{\mathrm{a}}$ の関係は必ずしも修正グッドマンの式ですべて表

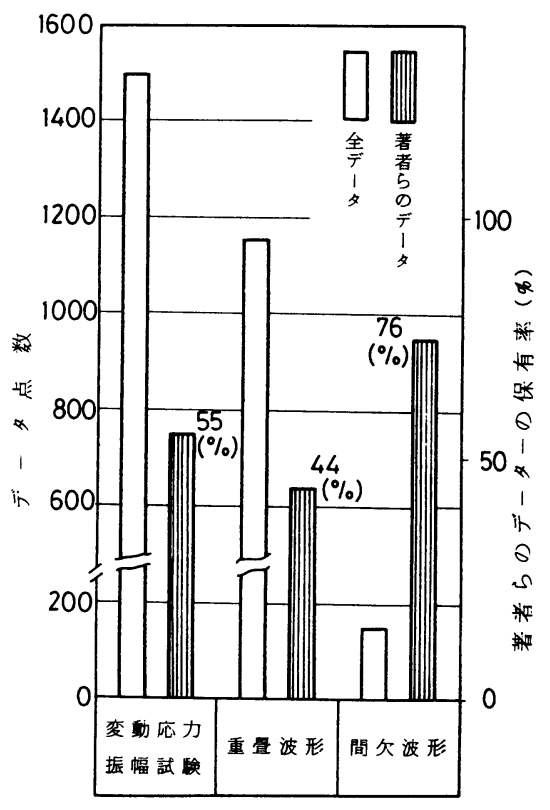

図 6 実㗢条件下の実験データの概数 
されるとは限らず，かなり複雑である ${ }^{20)}$. しかし，重畳 波形下の実験結果は修正グッドマンの式を用いると，ば らつきはあるがかなりよく説明できることが分っている. 平均応力が一定の場合と, 変動する場合とでその挙動が 異なっているのかむ分らないが，いずれにしろ寿命の推 定精度を上げるには今後解明すべき課題である.

以上，寿命推定におりる問題点について簡単に述べた が, 現状では応力解析結果から出発して, 疲労寿命の推 定までの流れの大筋ができた段階である. とくに推定寿 命と実際の寿命の比較を行っているのはピストンクラウ ンやシリンダカバーなどのディーゼル機関燃焼室壁部材

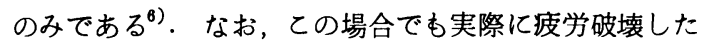
例があるので, それを勘案しながら学問的に罗当な考え 方をまとめたのが現状であり，上記の問題点については 今後の研究にまたねばならない，とくに実験室的には切 欠きをつけた試験片を使って間欠波形や重畳波形下の実 験を行って，上記の図 1 に示した流れにそって寿命評価 を行い，その妥当性を検討しなければならない。

\section{5.あとがき}

疲労寿命評価の面から舶用機関の主要部材に関するこ とがらを簡単に述べた．不明な点す幾つかあり，厳密に 考えれば寿命評価は困難となるが，製品は作られ，稼動 しているので, 過去の経験を最近の知識を使って見直し, その中から得られる知見を寿命評価に反映させながら現 製品の安全性を評価しているのが実情である.

最後に，ててでとりまとめたことが関係者ので参考に なれば幸いであるとともに，今後この方面の研究の発展 を期待したい.

\section{文献}

1） K.ルター，舶機誌，16-4(昭 56-4)，p.359.

2) 千葉，舶機誌，17-5(昭 57-5)，p.369.

3）犬伏，ガスタービン学会誌, 8-31(1980), p.20.

4) 中村, 田中共著, 機械の疲れ寿命算出法(昭 47-5), 養 賢堂.

5) 中村 (宏), 他 3 名, 舶機誌, 17-2(昭 57-2), p. 108 .

6）たとえば, 中村陽一，舶用ディーゼル機関の燃焼室壁部 材の設計の最適化と疲労寿命設計法に関する研究(学位論 文), 京都大学(昭 57-2).

7）中村(宏)，他 2 名，材料，22-234 (昭 48-3)，p.182.

8）中村(陽), 他 2 名, 材料, 30-335(昭 56-8), p.809.

9）堀川, 他 2名; 機論, 45-392(昭 54-4), p.293.

10) 中村, 他 2 名, 材料学会第 20 回高温強度シンポジゥム (昭 57-9), p.33.

11) H. Neuber, Theory of Notch Stresses, J. W. Edwards, Ann. Arbor Michigan, 1946.

12）公江, 他 2 名, 材料, 27-300 (昭 53-9), p.847.

13）たとえば, N. E. Frost, et al., Metal Fatigue, Oxford Univ. Press, 1974

14）たとえば, 中村, 他 2 名, 機械の研究, 31-10 (1979), p. 1222 .

15) 岡田, 他 4 名, 航空宇宙学会第 23 回講演会 (昭 58-2), p.10.

16）中村(宏), 他 2 名, 機械の研究, 31-7(1979), p.881.

17）中村(陽), 他 2 名，材料，30-335(昭 56-8)， p.809.

18）たとえば, 中村(宏), 他 4 名, 機論, 38-312 (昭 47-8), p. 1915 .

19）たとえば, 中村(宏), 堀川，機論, 36-287 (昭 45-7), p. 1059 .

20）井手, 他 3 名, 材料学会第 32 期通常総会講演会前刷集, (昭 58-5), p. 4 .

21）高杉, 他 3 名, 材料, 32-356 (昭 58-5), p.471.

22）蔦, 山地, 機誌, 76-651 (昭 48-3), p.348. 